Acta vet. scand. $1986,27,145-158$.

From the Department of Obstetrics and Gynaecology, Swedish University of Agricultural Sciences, Uppsala, Sweden.

\title{
THE EFFECT OF A BACTERIAL ENDOTOXIN OR CLOPROSTENOL ON THE CLINICAL STATUS AND HORMONAL LEVELS IN 80-100 DAYS PREGNANT GILTS
}

\author{
By \\ Nicholas Cort and Hans Kindahl
}

\begin{abstract}
CORT, NICHOLAS and HANS KINDAHL: The effect of a bacterial endotoxin or cloprostenol on the clinical status and hormonal levels in 80-100 days pregnant gilts. Acta vet. scand. 1986, 27, 145-158. An experiment was conducted to examine the effect of a lipopolysaccharide (LPS) of Salmonella typhimurium on the luteal function in 80 days pregnant gilts. Four animals were i.v. injected with $2 \mu \mathrm{g}$ LPS/kg body weight and 3 animals were i.m. injected with $500 \mu \mathrm{g}$ cloprostenol (CP). Gilts which maintained pregnancy after the initial injection were reinjected with $\mathrm{CP}$ around day 100 . Clinical observations were made and plasma levels of 15-keto-13,14-dihydro-PGF $2 \alpha$, progesterone, oestradiol-17 $\beta$ and oestrone sulphate were analysed by radioimmunoassay.

The LPS induced a characteristic clinical endotoxemia. All LPS treated gilts maintained pregnancy until day 100 when 1 gilt aborted, 1 was emergency slaughtered and 2 reinjected. The comparative injections of CP induced abortion within $48 \mathrm{~h}$ in 2 of 3 gilts at 80 days and in all reinjected animals at 100 days of pregnancy. Progesterone decreased immediately after both LPS and CP injections. In nonaborting gilts, the progesterone decrease had a transient character. The $\mathrm{PGF}_{2 \alpha}$ metabolite levels responded to LPS by a dramatic surge of approximately $4 \mathrm{~h}$ duration. All abortions were accompanied by a massive release of $\mathrm{PGF}_{2 \alpha}$ reaching peak levels during expulsion of the foetuses. Oestradiol-17 $\beta$ and oestrone sulphate followed an ascendent pattern between days 80 and 100 . Occasional transient decreases in oestradiol-17 $\beta$ or increases in oestrone sulphate levels after LPS and CP injections were observed in several animals. Abortions were followed by a sharp decrease of both oestrogens. Post-abortum reproductive disorders occurred frequently. Endocrine changesi associated with post-abortum ovarian activity were relevant to the clinical and morphological observations. The relationship between the stage of pregnancy in the pig and its endocrine response to abortifacient agents as well as some foetopathic effects of the endotoxin are discussed.
\end{abstract}

gestation; prostaglandin; steroid hormone a n a lysis. 
Studies by Roberts et al. (1975) and Anderson et al. (1975) confirmed that endotoxins of Gram-negative bacteria are able to synthetize and release $\mathrm{PGF}_{2 \alpha}$ in the uterus in sheep and in the lungs in calves, respectively. Administration of an endotoxin to gilts between 60 and 77 days of pregnancy caused abortions within $48 \mathrm{~h}$ (Wrathall et al. 1978, Cort 1986). Large amounts of endogenous $\mathrm{PGF}_{2 \alpha}$ released by the endotoxins most probably induced a rapid functional luteolysis, decrease of progesterone levels and termination of pregnancy (Cort et al. 1986). This conclusion was supported by the identical course of abortions induced by cloprostenol in the same study. Concerning the early post abortum period, the uterine involution and return of the ovaries to cyclic function progressed without complications. Several animals which did not abort to the luteolytic substances at 60 days, have not aborted either to multiple administrations of cloprostenol and/or endotoxin during a period of 70-100 days of pregnancy. Resistance to high doses of cloprostenol together with somewhat decreased durations of endotoxin-induced $\mathrm{PGF}_{2 \alpha}$ surges and little response of the progesterone levels indicated that a certain form of increased protection against luteolytic agents may have been taking place in the later pregnancy.

Vulnerability of pig pregnancy to premature termination probably comes to a breakpoint by day 100 after which the conceptus apparently reaches the stage of maturity when its endocrine system is able to initiate the hormonal cascade that culminates in parturition (First \& Bosc 1979).

The changes in hormonal pattern from day 60 to 80 of pregnancy in pigs include substantially elevated levels of oestradiol$17 \beta$ and oestrone sulphate and slighly decreased level of progesterone (Robertson \& King 1974). Endogenous $\mathrm{PGF}_{2 \alpha}$, which is reliably monitored by analysis of its plasma metabolite, 15keto-13,14-dihydro-PGF ${ }_{2 \alpha}$ (Kindahl et al. 1976), maintains low levels (Cort et al. 1986). The aims of this work were:

- to examine in general the effect of endotoxin and cloprostenol on the clinical status and the course of gestation in pigs at 80 days of pregnancy,

- to study the relationship between the stage of pregnancy and its endocrine response to abortifacient agents, and

- to study the post abortum period to 80 days of pregnancy and compare the consequences of the abortions to those earlier described at 60 days of pregnancy in pigs. 


\section{MATERIAL AND METHODS}

Seven pregnant gilts of Yorkshire/Landrace crossbreed were purchased from commercial herds and during the experimental period housed individually and fed a standard ratio. Prior to the experiment pregnancy was confirmed by a Doppler-effect instrument (Medata Systems Ltd., Yapton, GB).

Jugular venous blood was collected via silastic catheters inserted surgically (Rodriguez \& Kunavongkrit 1983) approximately 5 days before the experiments. Blood samples were immediately contrifuged and plasma stored at $-20^{\circ} \mathrm{C}$. Samples were frequently collected $2 \mathrm{~h}$ before (b.i.) and $48 \mathrm{~h}$ after (a.i.) the injection plus at least once a day as long as the catheters remained patent.

The endotoxin, a saline solution of a lipopolysaccharide (LPS) of Salmonella typhimurium SH 4809 (Svenson \& Lindberg 1978, Lindberg et al. 1983) was injected i.v. in a dose of 2 $\mu \mathrm{g} / \mathrm{kg}$ body weight (b.w.) into 4 gilts at 80 days of pregnancy. Cloprostenol (CP) (Estrumat, LEO AB, Sweden) was injected i.m. in a dose of $500 \mu \mathrm{g}$ into 3 gilts at 80 days of pregnancy. The actual day of injection differed from the planned by at most \pm 1 day. All gilts were clinically examined periodically throughout the experimental period. Animals which maintained pregnancy after injection at 80 days were reinjected with CP at 100 days of pregnancy. The condition of the ovaries and uterus in gilts postabortum (p.a.) was examined by laparoscopy (Wildt et al. 1973). Follicular structures of diameter exceeding $15 \mathrm{~mm}$ were classified as ovarian cysts. Aborted foetuses with placentas were anatomically examined as well as the uteri and ovaries of all gilts after slaughter. The plasma levels of progesterone, 15-keto-13,14-dihydro-PGF ${ }_{2 \alpha}$, oestradiol-17 $\beta$ and oestrone sulphate were determined by radioimmunoassay (RIA) according to methods described earlier (Cort et al. 1986).

\section{RESULTS}

The CP treated gilts showed a.i. no signs of clinical disturbance. The LPS treated animals developed general signs of acute endotoxemia such as elevated body temperature, dyspnea, tachycardia etc. which ceased within $4-5 \mathrm{~h}$ a.i. Clinical effects of CP and LPS on pregnancy are summarized in Table 1. While 2 of 3 CP treated gilts aborted within $48 \mathrm{~h}$, all of the LPS treated gilts 
maintained pregnancy until day 100 . Gilt 4 , having been injected by LPS on day 80 , aborted on day 100 of pregnancy. Two of the 10 aborted foetuses bore signs of advanced autolysis with necrotially degenerated placental segments. Gilt 5 was slaughtered on day 100 of pregnancy after suffering severe clinical complications related to an acute inflammation in a hind leg. Necropsy did not show any macroscopic signs of damage to foetuses. Reinjections of gilts 3 and 6 on day 100 resulted in abortions within $48 \mathrm{~h}$. Gilt 7 which did not abort to a LPS injection on day 99 was 4 days later treated with CP and aborted. Dimensions of the aborted foetuses and membranes were relevant to the stage of pregnancy and no signs of foetal death earlier than at abortion were observed.

Table 1 summarizes the occurrence and duration of oestrous symptoms in gilts p.a. The condition of reproductive organs was examined by laparoscopy and/or at necropsy after slaughter. The main observations concerning the ovaries can be described as corpora lutea of gravidity (c.l. grav.), periodic corpora lutea (c.l.) and cysts.

T a ble 1. Clinical data on pregnant gilts injected by cloprostenol (CP) and lipopolysaccharide (LPS) between days 80 and 100 of pregnancy.

\begin{tabular}{|c|c|c|c|c|c|c|c|c|c|}
\hline \multirow{2}{*}{$\begin{array}{l}\text { Gilt } \\
\text { no. }\end{array}$} & \multicolumn{2}{|c|}{$\begin{array}{c}\text { Injection } \\
\text { day }\end{array}$} & \multirow{2}{*}{$\begin{array}{c}\text { Abortion } \\
\text { day }\end{array}$} & \multicolumn{3}{|c|}{ Interval between } & \multicolumn{2}{|c|}{ Ovarian condition } & \multirow[t]{2}{*}{ Comments } \\
\hline & 80 & 100 & & $\begin{array}{l}\text { injection } \\
\text { /abortion } \\
\text { (h) }\end{array}$ & $\begin{array}{l}\text { start/end } \\
\text { abortion } \\
\text { (h) }\end{array}$ & $\begin{array}{c}\text { abortion } \\
\text { /oestrus } \\
\text { (days) }\end{array}$ & $\begin{array}{l}\text { p.a. } \\
\text { day }\end{array}$ & observation & \\
\hline 1 & CP & & 82 & 44 & 24 & & 5 & c.l. grav. & $\begin{array}{c}\text { Emergency slaughter } \\
\text { day } 5 \text { p.a. }\end{array}$ \\
\hline 2 & CP & & 82 & 44 & 8 & $\begin{array}{c}4 \\
22-23\end{array}$ & $\begin{array}{r}7 \\
28\end{array}$ & $\begin{array}{l}\text { cysts + c.l. } \\
\text { c.l. }\end{array}$ & \\
\hline 3 & CP & CP & 102 & 36 & 8 & $1-9$ & $\begin{array}{r}5 \\
16\end{array}$ & $\begin{array}{l}\text { cysts } \\
\text { cysts }+ \text { c.l. }\end{array}$ & \\
\hline 4 & LPS & & 100 & $(500)$ & 9 & & 2 & c.l. grav. & $\begin{array}{c}\text { Emergency slaughter } \\
\text { day } 2 \text { p.a. }\end{array}$ \\
\hline 5 & LPS & & none & & & & & & $\begin{array}{c}\text { Emergency slaughter } \\
\text { day } 100\end{array}$ \\
\hline 6 & LPS & CP & 102 & 28 & 9 & $1-2$ & 21 & cysts & \\
\hline 7 & LPS & $\begin{array}{l}\text { LPS } \\
\text { CP* }\end{array}$ & 105 & 39 & 13 & $2-3$ & $\begin{array}{l}22 \\
28\end{array}$ & $\begin{array}{l}\text { c.l. } \\
\text { c.l. }\end{array}$ & \\
\hline
\end{tabular}

Column "Interval between abortion/oestrus" gives also durations of oestrous symptoms.

* Injected on day 103. 
Gilts 1 and 4 were emergency slaughtered under severe clinical signs of an acute infection. Necropsy showed incompletely involuted uteri with signs of metritis in both animals.

Figs. 1 and 2 give examples of hormonal responses to injections of CP and LPS respectively. Fig. 3 presents the hormonal pattern in gilt 4 after treatment by LPS. Levels of progesterone varied between 20 and $40 \mathrm{nmol} / \mathrm{l}$ towards day 80. CP and LPS injections in all gilts were followed by a rapid decrease, which in aborting gilts reached levels $<5 \mathrm{nmol} / \mathrm{l}$ by the onset of the abortion. Low levels of progesterone were maintained until the first ovulation p.a. (Fig. 1). Decrease of progesterone in gilts $3-7$ had a transient character, with minimal levels of $28-10$ nmol/l which rose to previous high levels within $1-4$ days. The high level of progesterone in gilts 3,6 and 7 was maintained until reinjection at 100 days of pregnancy (Fig. 1). The spontaneous abortion in gilt on day 100 was preceded by a gradual decrease of progesterone beginning day 95 (Fig. 3).

The $\mathrm{PGF}_{2 \alpha}$ metabolite, which maintained levels below 1 nmol/l towards day 80 of pregnancy, did not show any direct

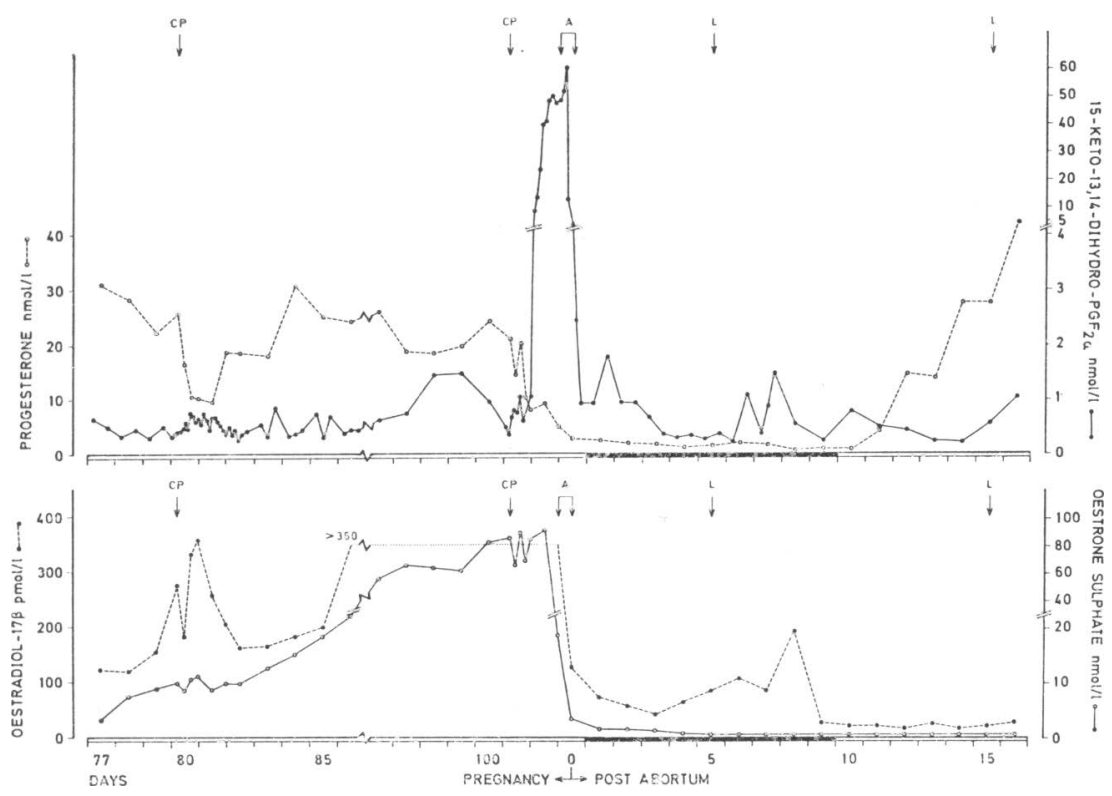

F ig u r e 1. Plasma levels of progesterone, 15-keto-13,14-dihydro$\mathrm{PGF}_{2 \alpha}$, oestradiol-17 $\beta$ and oestrone sulphate after $500 \mu \mathrm{g}$ CP on days 80 and 101 in gilt 3. Arrows mark injections (CP), the abortion (A) and the laparoscopy $(\mathrm{L})$. The horizontal black bar marks the oestrus. 

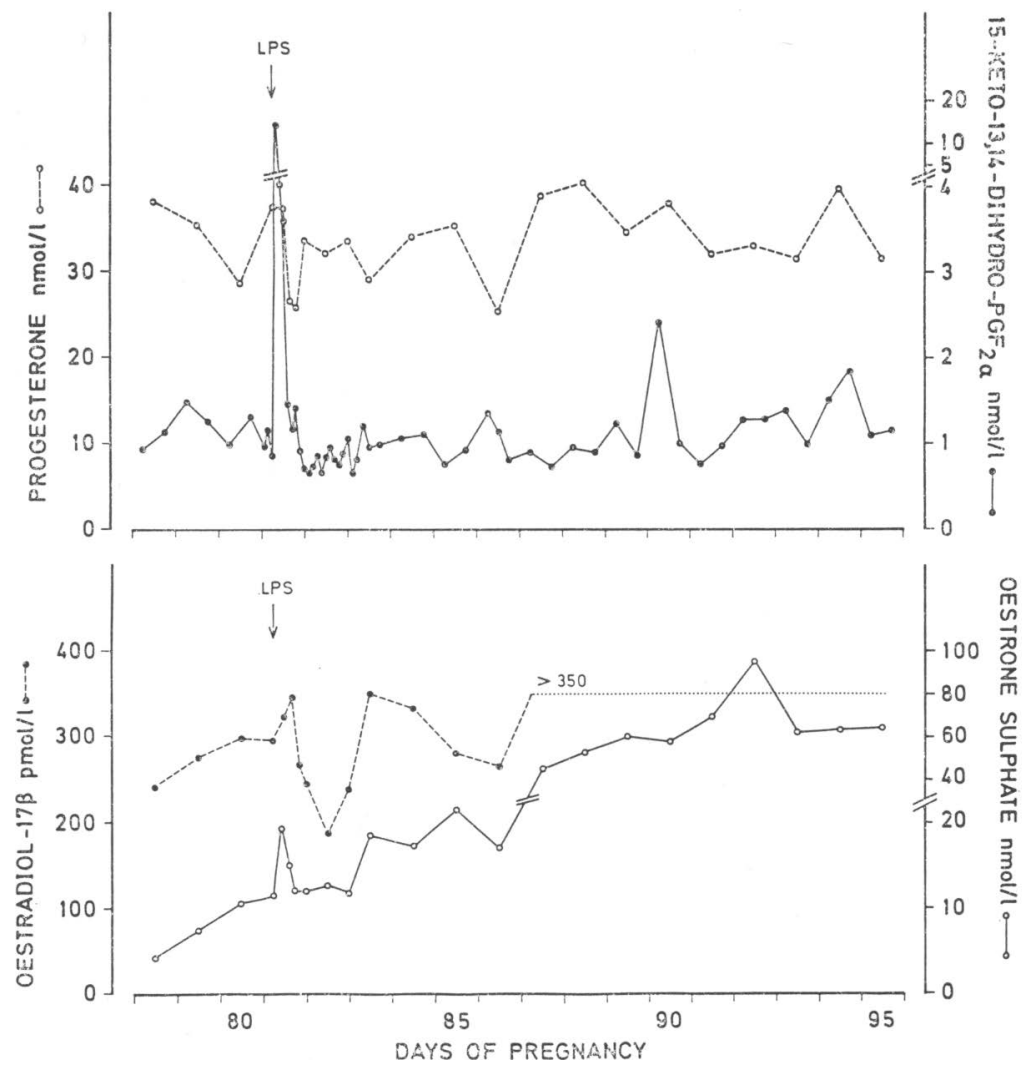

F ig u r e 2. Plasma levels of progesterone, 15-keto-13,14-dihydro$\mathrm{PGF}_{2 \alpha}$, oestradiol-17 $\beta$ and oestrone sulphate after $2 \mu \mathrm{g} / \mathrm{kg}$ b.w. LPS in gilt 7. Arrow marks the injection (LPS).

response to CP injections (Fig. 1). Gilts injected by LPS immediately responded by a dramatic surge to peaks of $3.6-15$ nmol/l lasting between $3-5 \mathrm{~h}$ (Figs. 2 and 3 ). The successive low levels were interrupted by occasional peaks to less than 2.5 nmol/l. All abortions were preceded by a substantial increase in the 15-ketodihydro-PGF ${ }_{2 \alpha}$ levels to peaks of $60-75 \mathrm{nmol} / \mathrm{l}$ which coincided with the onset of expulsion of the foetuses. The rise occurred within $12 \mathrm{~h}$ of the abortifacient injection and lasted $30-50 \mathrm{~h}$ (Fig. 1). A gradual increase of the $\mathrm{PGF}_{2 \alpha}$ metabolite level in gilt 4 began at 90 days of pregnancy and reached a peak of $113 \mathrm{nmol} / \mathrm{l}$ at the onset of the abortion (Fig. 3). Additional peaks of 15 -ketodihydro-PGF $2 \alpha$ were observed within 24 h p.a. in most of the animals (Figs. 1 and 3 ). 


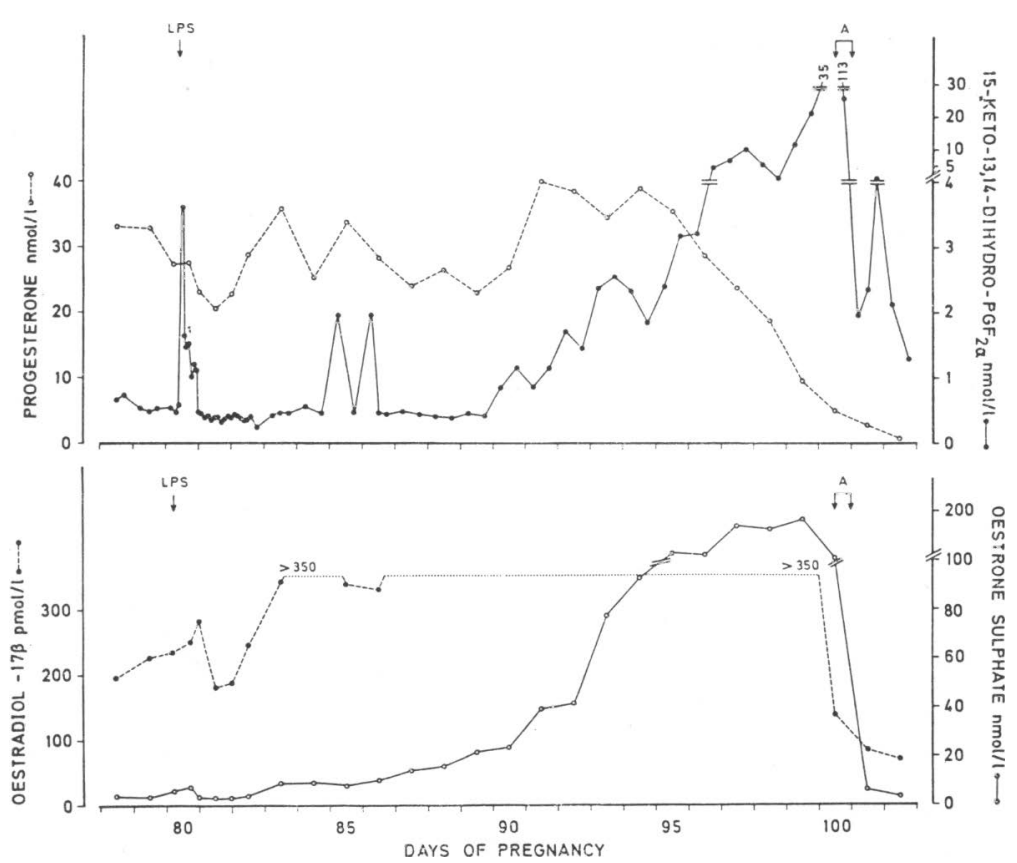

F i g u r e 3. Plasma levels of progesterone, 15-keto-13,14-dihydro$\mathrm{PGF}_{2 \alpha}$, oestradiol-17 $\beta$ and oestrone sulphate after $2 \mu \mathrm{g} / \mathrm{kg} \mathrm{b.w.} \mathrm{LPS} \mathrm{in}$ gilt 4. Arrows mark the injection (LPS) and the abortion (A).

Oestradiol $17 \beta$ ranging between $150-300 \mathrm{pmol} / \mathrm{l}$ by day 80 responded to CP by a marked depression of the level in gilt 3 between days 81 and 85 of pregnancy, while no particular response was observed in gilts 1 and 2. Gilts 4,5 and 7 responded to LPS injection on day 80 by a decrease in oestradiol-17 $\beta$ levels (Fig. 2) while the pattern remained undisturbed in gilt 6 . The hormone continued to rise as pregnancy progressed. Oestrone sulphate, reaching levels of about $10 \mathrm{nmol} / 1$ by day 80 , responded to CP in gilt 2 and to LPS in gilts 5 and 7 by a transient rise to $15-20$ nmol/1 lasting about $12 \mathrm{~h}$ (Fig. 2). Remaining animals showed no particular response to the injections and the pattern of oestrone sulphate in non-aborting gilts continued its rise towards late pregnancy. Abortions were followed by a sharp decrease in both oestrogens. The $\mathrm{PGF}_{2 \alpha}$ metabolite remained on low levels in all gilts p.a.

Oestradiol-17 $\beta$ maintained somewhat elevated plasma concentration in gilts which developed ovarian cysts (Fig. 1). Ovula- 
tory oestrus was preceded by a typical rise of oestradiol-17 $\beta$ and followed by an increase in progesterone levels. The hormonal patterns confirmed ovulatory oestrus in gilt 2 on days 4 and 22 p.a., in gilt 3 on day 9 p.a. (Fig. 1) and in gilt 7 on days 3 and 24 p.a. (Table 1 ).

\section{DISCUSSION}

The clinical manifestation of the endotoxemia was typical and has not differed from earlier observations (Wrathall et al. 1978, Cort 1986). The mean interval between a CP injection and abortion was approximately $38 \mathrm{~h}$. Very similar observations were made by Podany' et al. (1982) and Cort (1986). Up to day 100, the stage of pregnancy has apparently little effect on the duration of the interval which seems rather constant once that functional luteolysis along with progesterone decline took place. The mean duration of the abortions was approximately $12 \mathrm{~h}$ (range 8-24 h) which is nearly twice that in 60 days pregnant gilts (Cort 1986) and consistent with the resuls of Podany et al. (1982). This may depend on the fact foetuses at $80-100$ days of pregnancy are much bigger than at 60 days, thus making the expulsion more laborious and longer. Mature foetuses et term actively participate in the expulsion process (Ellendorf et al. 1979) which is probably not the case for foetuses delivered $2-5$ weeks prematurely. Concerning the hormonal management of the expulsion process, high levels of relaxin and oxytocin are known for their importance for the labour at term (Sherwood et al. 1975, Ellendorf et al. 1979). These might not be available in adequate amounts during 80-100 days of gestation.

Four of six aborted gilts showed oestrous symptoms within 1-4 days p.a. (Table 1). This is often observed in early postpartum sows and is probably due to the decreasing but still relatively high oestrogen levels of placental and foetal origin and low levels of progesterone (Holness \& Hunter 1975). Accordingly, oestrus in early post-partum sows was most often found anovulatory (Baker et al. 1953). However, in the present study 2 of 4 animals, showing oestrus within 4 days p.a., ovulated. Gilt 3 (Fig. 1) displayed oestrous symptoms for 9 days under increased levels of oestradiol-17 $\beta$ which was probably of placental origin during the first 2-3 days p.a. and was maintained by the cystic follicles until days 9 p.a. when ovulation took place. 
Plasma levels of 15-ketodihydro- $\mathrm{PGF}_{2 \alpha}$ in $\mathrm{CP}$ treated gilts maintained a.i. an unchanged low profile as the plasma levels of the $\mathrm{PGF}_{2 \alpha}$ analogue remained undetected in the $\mathrm{PGF}_{2 \alpha}$ metabolite assay (Kindahl et al. 1980). Surges of the $\mathrm{PGF}_{2 \alpha}$ metabolite after LPS injections reached similar peak levels as in 60 days pregnant gilts (Cort et al. 1986), however, the mean duration of $4.5 \mathrm{~h}$ was less than half of that at 60 days. A shorter duration of $\mathrm{PGF}_{2 \alpha}$ response to LPS in late pregnant gilts was observed, but due to its rarity not discussed, in an earlier study (Cort et al. 1986). The massive release of $\mathrm{PGF}_{2 \alpha}$ during all abortions corresponded to that at 60 days both in magnitude and duration. Additional peaks of $\mathrm{PGF}_{2 \alpha}$ after expulsion of the foetuses are most likely released by the uterus during involution which was apparent at 80 and 100 days of pregnancy as well as at term (Kindahl et al. 1982) but not at 60 days (Cort et al. 1986). The general decrease of progesterone prior to abortions as well as the temporary progesterone decrease after $\mathrm{CP}$ injection at 80 days (Fig. 1) were identical to those seen at 60 days (Cort et al. 1986). Progesterone responses to LPS injections, none of which caused an abortion within $48 \mathrm{~h}$ in the present study, were substantially less prominent. The decreases were smaller and of shorter duration than that after CP injecion. The reason for this may be the shortened release of $\mathrm{PGF}_{2 \alpha}$ due to a certain antiluteolytic mechanism or an efficient luteotropic protection of the source of progesterone.

A mechanism may be described as antiluteolytic when it blocks synthesis and/or release of a luteolytic substance or prevents the luteolysin from reaching the c.l. This is known to take place during the "maternal recognition of pregnancy", between 12 and 20 days of gestation in the pig, when uterine $\mathrm{PGF}_{2 \alpha}$ is redirected from an endocrine to exocrine secretion by foetal oestrogens and thus the c.l. of pregnancy are maintained (Bazer et al. 1982). Whether the increasing levels of oestrogens during 80 100 days of pregnancy elicit any uterine antiluteolytic effect is not known. Changes in oestradiol-17 $\beta$ and oestrone sulphate levels after the LPS and CP treatments have neither in the present study nor in the previous one (Cort et al. 1986) shown any systematic tendency and seem more like individual responses.

Maintenance of progesterone secretion from the late pregnancy c.l. in the pig is dependent on pituitary luteotropic support (Wrathall 1980). Data implicating luteinizing hormone (LH) 
and prolactin (PRL) as the luteotropic hormones were summarized by Wrathall (1980) and First \& Bosc (1979), respectively. However, some evidence was gathered that neither LH (First et al. 1982) nor PRL (Bazer \& First 1983) were essential for maintenance of pregnancy beyond day 70 in the pig. Cort et al. (1986) failed to observe any LH reponse to LPS injections at 60 days of pregnancy. $\mathrm{PGF}_{2 \alpha}$ administered to late pregnant sows increases levels of PRL (Taverne 1979) and corticoids (Wettemann et al. 1977). An Escherichia coli endotoxin caused in gilts 2 days post-partum dramatic increase of cortisol levels and marked decrease of PRL (Smith \& Wagner 1984). In pregnant gilts an endotoxin-induced increase in corticoid levels would have been expected to mediate termination of the pregnancy (First \& Bosc 1979, Wrathall 1980). The response and the role of prolactin remains to be determined.

Gilt 4 aborted 20 days after the endotoxin injection. A similar case was observed in a previous study (Cort 1986) where a gilt was emergency slaughtered probably within hours before an abortion caused by LPS injected 15 days earlier, In both cases the endotoxin did not cause a rapid luteolysis and abortion within $48 \mathrm{~h}$, but most likely killed 1 and 2 foetuses respectively which underwent post mortem autolysis. The clinical status of both mothers was critically affected. Furthermore, either the autolytic process itself or a certain reaction of the maternal endocrine system signalled an onset of an endogenous $\mathrm{PGF}_{2 \alpha}$ release, which eventually would cause an abortion. Though these two observations provide little evidence, it is possible that this sort of abortifacient mechanism occurs during natural infections by Gram-negative bacteria, where the release of endotoxin probably doesn't correspond to an i.v. administration of a purified lipopolysaccharide. Endotoxins are known to elicit a number of pathogenic effects on the placenta and foetus (Culbertson \& Osburn 1980). However, the reason for the observed "selective" lethal effect on some foetuses is unknown. Endotoxin treatment caused frequent foetal death but fewer abortions in mice (Skarnes \& Harper 1972). In the pig, killing of all foetuses after day 30 did not interfere with the c.l. function up to day 60 (Webel et al. 1975) and within $100-200$ days of pregnancy (Coggins $\&$ First 1977), provided the foetuses had not been absorbed. In advanced pregnancy, dead foetuses are not absorbed but undergo mummification and do not affect the course of pregnancy (e.g. 
Taverne 1979, Cort 1986). Thus the effect of LPS in the 2 gilts in the present and previous (Cort 1986) studies does not correspond to the reported independence of the pig gestation on the wellfare of the foetuses.

Abortion within days $80-100$ had a considerably more negative effect on p.a. ovarian function and clinical status than those in earlier pregnancy. One gilt of 6 developed p.a. ovarian cysts at 60 days of pregnancy (Cort 1986) while in the present study 3 of 6 gilts displayed p.a. cysts at least once (Table 1). A high rate of ovarian disorders was reported in post-partum zeroweaned sows (Kunavongkrit et al. 1983). These animals had also elevated plasma cortisol probably due to the stressing interference in the puerperium (Kunavongkrit et al. 1984). Stress corticoids together with high oestrogen levels may have affected the early p.a. ovarian function in gilts in the present study. Two gilts suffered p.a. metritis, one of which may have been initiated by the LPS-induced foetal death. The study indicates that the later in pig pregnancy an abortion occurs, the more reproductive disorders are to be expected afterwards.

\section{ACKNOWLEDGEMENTS}

The authors thank Catharina Falkenberg for technical assistance. Analyses of the steroid hormones were made in the Department of Clinical Chemistry, Swedish University of Agricultural Sciences. The endotoxin was kindly supplied by Dr. S. B. Svenson, Karolinska Institutet, Stockholm. Stipendium to N. Cort from the Swedish Institute, Stockholm, is acknowledged. This study was supported by the Swedish Council for Forestry and Agricultural Research.

\section{REFERENCES}

Anderson, F. L., T. J. Tsagaris, W. Jubiz \& H. Kuida: Prostaglandin F and $E$ levels during endotoxin-induced pulmonary hypertension in calves. Amer. J. Physiol. 1975, 228, 1479-1482.

Baker, L. N., H. L. Woehling, L. E. Casida \& R. H. Grummer: Occurrence of estrus in sows following parturition. J. Anim. Sci. 1953, 12, 33-38.

Bazer, F. W., R. D. Geisert, W. W. Thatcher \& R. M. Roberts: The establishment and maintenance of pregnancy. In: D. J. A. Cole \& G. R. Foxcroft (Ed.) Control of Pig Reproduction, pp. 227252, Buterworths, London 1982.

Bazer, F. W. \& N. L. First: Pregnancy and parturition. J. Anim. Sci. 1983, 57, Suppl. 2, 425-460.

Coggins, E. G. \& N. L. First: Effect of dexamethasone, methallibure and fetal decapitation on porcine gestation. J. Anim. Sci. 1977, 44, 1041-1049. 
Cort, N.: A clinical study on the effect of a Gram-negative bacterial endotoxin and cloprostenol in non-pregnant and 60 days pregnant gilts. Anim. Reprod. Sci. 1986, 10, 133-145.

Cort, N., H. Kindahl \& S. Einarsson: The effect of a Gram-negative bacterial endotoxin and cloprostenol on the plasma levels of 15-keto-13,14-dihydro- $\mathrm{PG}_{2 \alpha}$, progesterone, oestradiol-17 $\beta$, oestrone sulphate and luteinizing hormone in non-pregnant and 60 days pregnant gilts. Anim. Reprod. Sci. 1986, 10, 147-162.

Culbertson, Jr., R. \& B. I. Osburn: The biologic effects of bacterial endotoxin: A short review. Vet. Sci. Commun. 1980, 4, 3-14.

Ellendorf, F., M. Taverne, F. Elsaesser, M. Forsling, N. Parvizi, C. Naaktgeboren \& D. Smidt: Endocrinology of parturition in the pig. Anim. Reprod. Sci. 1979, 2, 323-334.

First, N. L. \& M. J. Bosc: Proposed mechanisms controlling parturition and the induction of parturition in swine. J. Anim. Sci. $1979,48,1407-1421$.

First, N. L., J. K. Lohse \& B. S. Nara: The endocrine control of parturition. In: D. J. A. Cole \& G. R. Foxcroft (Ed.) Control of Pig Reproduction, Butterworths, London 1982, pp. 311-342.

Holness, D. H. \& R. H. F. Hunter: Post-partum oestrus in the sow in relation to the concentration of plasma oestrogens. J. Reprod. Fert. 1975, 45, 15-20.

Kindahl, H., L.-E. Edqvist, E. Granström \& A. Bane: The release of prostaglandin $\mathrm{F}_{2 \alpha}$ as reflected by 15 -keto-13,14-dihydro-PGF $\mathrm{F}_{2 \alpha}$ in the peripheral circulation during normal luteolysis in heifers. Prostaglandins 1976, 11, 871-878.

Kindahl, H., J.-O. Lindell \& L.-E. Edqvist: On the control of prostaglandin release during the bovine estrous cycle. Effects of cloprostenol injections. Nord. Vet.-Med. 1980, 32, 467-473.

Kindahl, H., R. Alonso, N. Cort \& S. Einarsson: Release of prostaglandin $\mathrm{F}_{2 \alpha}$ during parturition in the sow. Zbl. Vet. Med. A. 1982, 29, 504-510.

Kunavongkrit, A., L.-E. Edqvist \& S. Einarsson: Clinical and endocrinological studies in primiparous zero-weaned sows: 3 . Hormonal patterns of normal cycling sows after zero-weaning. $\mathrm{Zbl}$. Vet. Med A. 1983, 30, 616-624.

Kunavongkrit, A., A. Madej \& S. Einarsson: Plasma levels of cortisol in zero-weaned and lactating sows during the first two weeks post partum. Dom. Anim. Endocrinology 1984, 1, 217-224.

Lindberg, A. A., G. E. Sheldon \& S. B. Svenson: Induction of endotoxin tolerance with nonpyrogenic 0 -antigenic oligosaccharide-protein conjugates. Infect. Immun. 1983, 41, 888-895.

Poda:'y, J., J. Vanicek, J. Stejskal \& L. Jelének: Induction of abortion with prostaglandin $F_{2 \alpha}$ in gilts and their subsequent fertility. Theriogenology 1982, 17, 393-400.

Roberts, J. S., B. Barcilkowski, L. Wilson, R. C. Skarnes \& J. A. Mc Cracken: Hormonal and related factors affecting the release of prostaglandin $\mathrm{F}_{2 \alpha}$ from the uterus, J. Ster. Biochem. 1975, 6, 1092-1097. 
Robertson, H. A. \& C. J. King: Plasma concentrations of progesterone, oestrone, oestradiol-17 $\beta$ and of oestrone sulphate in the pig at implantation, during pregnancy and at parturition. J. Reprod. Fert. 1974, 40, 133-141.

Rodriguez-Martinez, H. \& A. Kunavongkrit: Chronic venous catheterization for frequent blood sampling in unrestrained pigs. Acta vet. scand. $1983,24,318-320$.

Sherwood, D. D., C. C. Chang, G. W. BeVier \& D. J. Dziuk: Radioimmunoassay of plasma relaxin levels throughout pregnancy and parturition in the pig. Endocrinology 1975, 97, 834-837.

Skarnes, R. C. \& M. J. K. Harper: Relationship between endotoxininduced abortion and the synthesis of prostaglandin F. Prostaglandins 1972, 1, 191-203.

Smith, B. B. \& W. C. Wagner: Suppression of prolactin in pigs by Escherichia coli endotoxin. Science 1984, 224, 605-607.

Svenson, S. B. \& A. A. Lindberg: Immunochemistry of Salmonella 0-antigens: Preparations of an octasaccharide-bovine serum albumin immunogen representative of Salmonella serogroup B 0 -antigen and characterization of the antibody response. J. Immunol. 1978, 120, 1750-1757.

Taverne, M. A. M.: Physiological aspects of parturition in the pig. Thesis, University of Utrecht, The Netherlands 1979, $101 \mathrm{pp}$.

Webel, S. K., T. J. Reimers \& D. J. Dziuk: The lack of relationship between plasma progesterone levels and number of embryos and their survival in the pig. Biol. Reprod. 1975, 13, 177-186.

Wettemann, R. P., D. M. Hallford, D. L. Kreider \& E. J. Turman: Influence of prostaglandin $F_{2 \alpha}$ on endocrine changes at parturition in gilts. J. Anim. Sci. 1977, 44, 106-111.

Wildt, D. E., S. Fujimoto, J. L. Spencer \& W. R. Dukelow: Direct ovarian observation in the pig by mean of laparoscopy. J. Reprod. Fert. 1973, 35, 541-543.

Wrathall, A. E., C. Wray, J. Bailey \& D. E. Wells: Experimentally induced bacterial endotoxaemia and abortion in pigs. Brit. vet. J. 1978, 134, 225-230.

Wrathall, A. E.: Ovarian disorders in the sow. The Vet. Bull. 1980, $50,253-272$.

\section{SAMMANDRAG}

Effekten av ett bakteriellt endotoxin och cloprostenol på kliniskt status och hormonnivåer hos 80-100 dagars dräktiga gyltor.

Ett experiment utfördes för att undersöka effekten av endotoxin (lipopolysackarid (LPS) ) från Salmonella typhimurium på den luteala funktionen hos 80 dagars dräktiga gyltor. Fyra djur fick en i.v. dos av $2 \mu \mathrm{g} / \mathrm{kg}$ kroppsvikt LPS och 3 djur en i.m. dos av $500 \mu \mathrm{g}$ cloprostenol (CP). Gyltor som bibehöll dräktigheten efter den första injektionen blev ombehandlade med CP omkring dag 100. Kliniska observationer utfördes och plasmanivåer av 15-keto-13,14-dihydro-PGF ${ }_{2 \alpha}$, progesteron, östradiol-17 $\beta$ och östronsulfat analyserades med radioimmunologiska mätmetoder. 
Lipopolysackarid framkallade en karakteristisk klinisk endotoxemi. Alla gyltor behandlade med LPS bibehöll dräktigheten fram till dag 100 då en gylta aborterade, en blev nödslaktad och 2 ombehandlades. Cloprostenolinjektioner orsakade abort inom 48 timmar i 2 av 3 gyltor vid 80 dagar och i alla ombehandlade djur vid 100 dagars dräktighet. Progesteronnivåerna sjönk omedelbart efter både LPS och CP injektioner. Hos icke-aborterande gyltor hade progesteronminskningen en övergående karaktär. Nivåer av $\mathrm{PGF}_{2 \alpha}$ metaboliten reagerade på LPS med en dramatisk förhöjning varande ca 4 timmar. Alla aborter följdes av massiva frisättningar av $\mathrm{PGF}_{2 \alpha}$ med maximum under utdrivandet av kultingarna. Nivåer av östradiol-17 $\beta$ och östronsulfat ökade kontinuerligt mellan 80 och 100 dagar. Enstaka övergående minskningar i östradiol-17 $\beta$ nivå eller ökningar i östronsulfat nivå observerades efter LPS och CP injektioner hos flera djur. Aborter följdes av en skarp minskning av båda östrogenerna. Reproduktionsstörningar förekom frekvent efter aborterna såsom äggstockscystor. De endokrina förändringarna motsvarade de kliniska och morfologiska observationerna. Relationerna mellan olika dräktighetsstadier och de endokrina svaren på abortframkallande substanser liksom några fetopatiska effekter av endotoxiner diskuteras.

(Received January 9, 1986).

Reprints may be requested from: Nicholas Cort, the Department of Obstetrics and Gynaecology, Swedish University of Agricultural Sciences, S-750 07 Uppsala, Sweden. 